\title{
DOI: 10.7596/taksad.v8i3.2175
}

Citation: Holub, O., Shcherbakova, N., Lesyk, A., \& Serhiyenko, S. (2019). The Heritage of the Progressive Ukrainian educators of the Northern Azov Region (the Second Half of the 19th Century): The Historical and Pedagogical Aspects. Journal of History Culture and Art Research, 8(3), 201-208. doi:http://dx.doi.org/10.7596/taksad.v8i3.2175

\section{The Heritage of the Progressive Ukrainian educators of the Northern Azov Region (the Second Half of the 19th Century): The Historical and Pedagogical Aspects}

\author{
Olena Holub ${ }^{1}$, Nadiia Shcherbakova², Anzhelika Lesyk ${ }^{3}$, Svetlana Serhiyenko ${ }^{4}$
}

\begin{abstract}
The article reveals the approaches of progressive educators of Ukraine in the second half of the 19th century to the restructuring and modernization of the system of school education in the Northern Azov region. Their thorough study, critical thinking and assessment from the standpoint of modern pedagogy are among the sources of the development of today's pedagogical science. The pedagogical heritage of M. Korf and Ya. Novytskyi is of considerable interest to modern science, since their activity was important for the development of public education at the end of the 19th century, in particular in the Northern Azov region. The reformist views of these educators were aimed at the organization of general public education. The school, in their belief, was supposed to provide students with diverse humanitarian and real knowledge, to develop their ability to self-education, to promote the health of students, to develop aesthetic feelings in them. M. Korf paid a lot of attention to the preparation of teachers for pedagogical activities. In practice of Ya. Novytskyi the use of advanced teaching methods draws attention, in which a significant place was given to practical teaching methods. In the context of the problem under study, this provides an opportunity to enrich the modern pedagogy of the school, in particular, the primary school, idea of the organization, the content of the training of younger students, and the professional training of the teacher.
\end{abstract}

Keywords: The Northern Azov region; Zemsky schools; Organization of universal education; Folkloristic activity; Studying in zemsky schools.

\footnotetext{
${ }^{1}$ Berdyansk State Pedagogical University. E-mail: dove_ov@ukr.net

2 Berdyansk State Pedagogical University. E-mail: nadiya030219@ukr.net

${ }^{3}$ Berdyansk State Pedagogical University. E-mail: as_lesyk@ukr.net

${ }^{4}$ Berdyansk State Pedagogical University. Correspondence E-mail: as_lesyk@ukr.net
} 


\section{Introduction}

At the present stage of development of society in Ukraine, one of the most urgent is the problem of modernization of the educational system, an important and decisive element of which is the institution of general secondary education. To achieve success in reforming the modern school and to solve many relevant problems in a new way, studying, rethinking, and using progressive pedagogical ideas of the past in the practice of the educational process will help.

In the history of the development of pedagogical thought, the ways of solving the problems associated with the organization of school education and the training of future teachers for the performance of professional duties are reflected in the works of theoretical direction and practical experience of teachers of the past, in particular, O. Dukhnovych, M. Korf, T. Lubinets, S. Myropolskyi, Ya. Novytskyi, S. Rusovaand, and others. Their pedagogical dedication and ideas for improving education inspire seminal work and search for ways to build a new Ukrainian school, predict the system of training and retraining of a modern teacher.

A special reference in this context is the appeal to the pedagogical heritage of educators of the Northern Azov region of the second half of the 19th and the beginning of the 20th century $-\mathrm{M}$. Korf and Ya. Novytskyi. Their names have been unfairly forgotten for a long time, but their pedagogical achievements are special in the formation and development of public education in Ukraine and are still necessary to improve the educational process in the educational institutions of Ukraine. Therefore, modern pedagogy returns to the study of this problem.

Pedagogical experience and results of a number of scientific investigations (M. Antoshchak, L. Vovk, L. Hutsal, K. Yelnytskyi, V. Zhylinskyi, I. Kocherhin, I. Kushnirenko, M. Pieskovskyi, V. Pavlenko, O. Popelniukh, S. Saiapina, I. Shumilova and others) show that the pedagogical ideas of the educators of the designated time interval were crucial for the formation of the national idea and national mentality, the development and preservation of Ukrainian culture, the development of pedagogical thought, taking into account regional peculiarities.

The purpose of this article is that on the basis of a retrospective analysis of the pedagogical heritage of $\mathrm{M}$. Korf and his follower Ya. Novytskyi revealing the influence of their ideas on the development of modern education in Ukraine.

\section{Discussion}

The second half of the 19th century can be considered a special period of formation and development of public education in the Northern Azov region. The abolition of serfdom in Russia created hopes for improving the economic, social, and cultural life of the state. In fact, this was a period when reforms began in the financial sector, the army, and the court. In such conditions, it is realistic to expect changes in the field of education, especially since, according to statistics, on the eve of the 1861 reform, only $3 \%$ of the population of Ukraine could read and write. Illiteracy of the masses prevented the development of capitalist relations in industry and agriculture, the solution of this problem has become a vital and necessary socio-economic and political problem.

According to L. Vovk, "1859-1895 years was an important period in the development of education. They were characterized by the emergence of progressive cultural and educational 
tendencies of society, advocating the interests of all people, its national spiritual culture and education" (1994). At this time, zemstva (bodies of local self-government) played an important role in the development of education, they were created on the Left Bank and south of Ukraine. Representing local interests, zemstva assumed responsibility for the development of elementary education. The composition of zemstva committees more often belonged to people who had unbiased progressive views on the development of education. It is also noteworthy that zemstva committees covered $85 \%$ of the school budget. Their goal was the construction of new premises in which they had to undergo training, improving teaching methods and teaching content. Thus, in zemsky schools, instead of religious texts, they introduced mathematics, history, and geography. Zemstva also appointed and paid the work of the teacher, they paid attention to the necessary teaching equipment, in particular, they supplied textbooks and visual aids, pencils, paints, booklets, pens, cards, class journals, etc. Schools created by zemstva had a three-year course of study, one teacher who conducted classes with three departments of students and thus they differed from the parochial schools by a more advanced organization of the educational process.

This was the time when an effective mechanism for zemstva's participation in the decisionmaking process on the compulsory activity of zemstva's public schools was created. The reorganization of general secondary schools was substantially carried out and the number of their students increased. Progressive teachers worked in such schools. Classes were conducted according to the textbooks by K. Ushunskyi, L. Tolstoi, M. Korf, and other outstanding educators.

M. Korf (1834-1883) and his follower and sincere friend Ya. Novytskyi (1847-1925) were active organizers of changes in zemsky schools; they prepared the groundwork for the formation of the theoretical foundations for the provision of quality education, as well as the creation of appropriate conditions for its practical implementation. In particular, the active and creative work of $\mathrm{M}$. Korf caused the priorities in the organization of universal education of pupils in zemsky schools and in the professional training of future teachers of that time.

M. Korf in his writings first substantiated the strategic direction of development of all components of the pedagogical system of zemsky school, he specified the purpose, tasks, principles, content, forms, methods of teaching and upbringing of elementary school students, as well as determined the need for changes in the vocational training and retraining of teachers for zemsky school. It is valuable that Mykolai Aleksandrovich considered zemsky schools as a developmental, moral and religious institution, as well as a socially important institution that contributes to the understanding and assimilation of the system of knowledge about the surrounding world, the formation of generalized practical skills and skills that must be mastered by conscious citizens and good masters (Korf, 1886). Having started a new type of school - a three-year zemsky school with one teacher, who at that time often did not have special pedagogical training, M. Korf developed detailed plans of classes and methods of conducting them. The result of his fruitful work was the work "Repeat School Guide", which contained the program, notes, guidelines and homework assignments for lessons from all subjects of the school year (Korf, 1882). The purpose of schooling M. Korf saw in preparing the child for life in a real environment, in a particular society. He believed that the school should help the child take the path of independent and honest work and find his place in life. 
To facilitate the study of schoolchildren, he created textbooks "Malyutka" and "Our friend" whose content corresponded to the internal goal of zemsky education - the development of personality. They provided scientific information of practical significance for the future life and activities of students, contributed to the expansion of their outlook, the development of logical thinking. Korf noted, "conversations should give students less ready information and stimulate their thinking more ..." (1871). To do this, in the textbook "Our Friend", the task was formulated so that only the student who could not only remember, but also understand what he was reading could answer them.

Along with stories, fables in the same textbook, M. Korf also used a significant number of articles of everyday nature and technical content. They reveal the peculiarities of making clothes, utensils, agricultural implements, etc. The main task of these articles was to motivate students to think about life, to encourage them to seek the truth. An important condition for the realization of this task was the correct interpretation of the material presented by the teacher and the desire and ability to create conditions for meaningful learning.

The like-minded person who consciously shared these ideas was Yakov Novytskyi, a selfless, ideological follower and a sincere friend of Mykola Korf who was in love with his work. He is one of the first practicing teachers who implemented the idea of a work school in their own pedagogical work, where children learn from their own experience, which will then become their support in life. Ya. Novytskyi's innovative approaches to learning subsequently gained recognition not only in Ukraine but also in many Western European countries and remain relevant to this day. After all, the main leitmotiv of the modern school in Ukraine is activity and competence approaches, which are based on humanistic principles. Dividing the idea of K. Ushunskyi and M. Korf on the developmental education of children in order to prepare them for future life and work, Yakov Pavlovich tried to introduce it into the educational process of zemsky schools. Ya. Novytskyi was critical of the traditional school programs of that time because they did not allow children to receive a proper education. Instead, he highly appreciated the textbooks created by K. Ushunskyi and M. Korf and used them in his pedagogical activities, which allowed the educator to get positive results. According to Ya. Novytskyi, these books contained valuable scientific information, they contributed to the expansion of the outlook of students, the development of their logical thinking, and of course, were of practical importance for future life and activities of students, which corresponded to the convictions of Ya. Novytskyi in relation to the goals and objectives of education at that time (Skilskyi, 2012).

Reports of zemstva's counties have information about the success of children who studied by "Native Word" by K.D. Ushunskyi. So, after the exams of the Fedoriv school students in 1883, Ya. Novytskyi wrote that he was watching that the children were able to read consciously, and this fact brought him great pleasure since it was pleasant to communicate not only with the whole group together but also with each student separately (Life record of Yakov Pavlovich Novytskyi. Ark. 10).

Ya. Novytskyi creatively fulfilled his duties as a teacher, using a material that was innovative by nature. Yakov Pavlovich acquainted students not only with compulsory school subjects (God's law, Russian and Slavic reading, writing, counting, singing, gymnastics, handicrafts) but also with history, geography, natural science, physics, hygiene, painting, drafting, etc. He noted that "social science, history, and geography of the homeland at school are not separate subjects, but due to their 
importance, the information is taken out by the children from the teacher's conversations during class reading lessons" (Life record of Yakov Pavlovich Novytskyi. Ark. 10).

It should be noted that in the schools of that time, methods aimed at cramming, hints, pupils' mechanical rewriting of the material, guessing the answers prevailed. This was seen and negatively evaluated by Ya. Novytskyi. He insisted on the need for a conscious attitude of children to learning, the development of their thinking, intelligence and independence in their judgments. Like K. Ushunskyi and M. Korf, he believed that the school should develop individual abilities, inclinations, and independence of the younger generation. In the opinion of teachers, in order to improve the quality of education, it is important to introduce a differentiated approach to learning, rely on the level of training of each student. Therefore, the work of zemsky schools, under the leadership of M. Korf and Ya. Novytskyi, was structured in such a way that each child could realize himself, his individual characteristics. Teachers were convinced that the development of pupils' mental forces, associated with the awakening of consciousness, is often ensured by including the child in activities and encouraging her maximum autonomy.

According to Ya. Novytskyi, the teacher's explanation of the new material should take the form of "living pictures". To facilitate learning, the teacher introduced such forms as excursions to nature, collection and design of collections of plants, animals, insects, and minerals. As documental materials evidence, during "excursions to the Dnieper and Khortytsya we had to collect a large collection of eggs, insects, and potions" (Biographical materials: official documents on the right to study, certificates of merit, 1862-1914). At the end of the third year of Ya. Novytskyi's work in the Voznesenskyschool, 20 scarecrows of animals and birds were made, during the excavation, many skulls were found that were used in history lessons; a collection of minerals also appeared (Novytskyi, 2007).

Since zemsky schools were organized mainly in rural areas, Ya. Novytskyi emphasized the need to prepare children for future agricultural work. For this, he offered to introduce into the school courses subjects in gardening, viticulture and beekeeping, and for the student's practice, create school "estates" and apiaries. These views of the educator were supported by his associates. At school, children learned the techniques of care for the gardens, and grown saplings were distributed free to the peasants. In another school, more time was spent on beekeeping. It is an interesting fact that, according to a school example, some peasants began to make apiaries.

In a short time, the school in which Ya. Novytskyi taught became one of the best in the county. Archival materials show that in 1870, M. Korf, in accordance with the decision of the school council, highly appreciated the pedagogical innovative activity of Ya. Novytskyi and materially encouraged him for excellent teaching.

It should be noted that the teacher persistently embodied his ideological convictions in the most difficult conditions, even at the time when, on the advice of $\mathrm{M}$. Korf, he went to work at another school, which was extremely neglected and not ready to implement advanced ideas. In some miraculous way, Ya. Novytskyi managed to "revive" the children: "sadness disappeared somewhere, cheerfulness and joy appeared, caused by the teacher's love for children", wrote M. Korf (1872).

So, this indicates that M. Korf and Ya. Novytskyi realized that the success of the school depends primarily on the teachers working in it. The ideas of $\mathrm{M}$. Korf that the teacher is a carrier of 
knowledge, which is not found in any other pedagogical source, remain relevant to this day. The teacher adds emotional coloring, gives a slightly tangible moral assessment of the knowledge, and therefore no other means of teaching can replace it. "As the most perfect organ can never replace an artist and the best photo is a work of an artist, so neither a printed edition can replace a living word, and no textbook can replace a teacher" (Korf, 1877).

According to M. Korf, for the development of the school and the solution of its tasks, teachers must be associates of their work, they should overcome difficulties encountering in their professional activities, work creatively. M. Korf considered teachers' seminaries and teacher's congresses as reliable sources for the training of such teachers. The training of teachers in seminaries will allow replacing priests, clerks, and sacristans, who taught in the schools of that time, with specially trained specialists who will be able to introduce new methods and approaches to teaching. M. Korf made a lot of efforts to open such seminaries because it stimulated the mass opening of schools (Korf, 1877).

Teacher congresses organized by M. Korf in the 1860-80s had an educational purpose and were considered as refresher courses. M. Korf considered a personal example as the best teaching method. That is why at congresses-courses he conducted open lessons, classes with teachers, which had a positive effect on the general education of teachers and the improvement of their methodological level. The laboratory for practical improvement of teachers was Vremevska School, located near the estate of baron M. Korf (Piskun, 1914).

In the period from 1873 to 1875 , all provincial zemstvas of Ukraine decided to hold short-term teacher courses annually during the summer holidays. This work with small interruptions during the deepening of the reaction was carried out by zemstvas constantly. So, the Aleksandrovsky zemstvo sent young teachers to a two-week practice to familiarize themselves with the advanced methods of teaching and educational work of the Olhinskaya rural exemplary school of the Mariupol district, which was headed at that time by Ya. Novytskyi. He successfully combined pedagogical activity with research, to which he paid a lot of attention and gained great experience and recognition among scientists. Ya. Novytskyiencouraged teachers to do ongoing research, believing that this would positively affect their pedagogical work and encourage them to involve children in research activities.

Another, not less important page of Ya. Novytskyi's work is a folkloristic activity, which he started in 1873. It defines the basic principles of collecting and publishing folk art: "We pass the word for word written by us from Ukrainians story, without translating it into Russian; we do this because we too much value each true word of the Ukrainian-narrator" (Novytskyi, 2007). He studied the history of the Northern Azov region not only by archaeological data but above all by folk stories, legends, songs, memoirs. The teacher actively involved students in this activity. Thus, many fairy tales were written by him and by the students themselves. For example, the fairy tale "Pea to the sky" told Hryhoriilysyi, who lived in the village Olhinske of Mariupol district; "Bychok tretiachok" is written from the words of Ivan Dombrovsky - student from the same village; "Kotyhoroshok"-from the words of the student Julian Khorunzhyifrom Malo-Mikhailovka village of the Alexander district (Novytskyi, 2007). 
The teacher's interest in the Ukrainian national culture caused discontent in the royal administration and Ya. Novytskyi for some time (1878-80) was excluded from the teaching for spreading Ukrainophile traditions among the people.

From 1883 to 1917, the Aleksandrovsky zemsky district regularly chose Ya. Novytskyias a school curator, twice a year he inspected them. In March, this was done for the purpose of inspecting students' knowledge, in May - with the aim of participating in final examinations. As a trustee of zemsky schools of the Aleksandrovsky district, Ya. Novytskyi often traveled, which deepened his knowledge of villages, rivers, beams, old ways, and graves. In constant communication with many peasants, especially with older people, he received interesting and valuable historical, folklore and ethnographic information, thus combining pedagogical and scientific activities.

Ya. Novytskyi also attracted his colleagues and teachers to historical and ethnographic expeditions. They allowed studying the history and geography of their native land, to collect folk material and photograph the terrain (State archive of Zaporizhzhya region, 1883).

The 1880s-90s are the years of fruitful activity of Ya. Novytskyi, in which he wrote the following words: "On the history of public education of the Yekaterinoslav province", "Results of public education in Aleksandrovsky district from 1866 to 1886", "First schools of the Alexander fortress and Alexander district city (1785-1880)", "Reports on the state of public education in the Aleksandrovsky district of the Yekaterinoslav province from 1881 to 1911 yr.", where the author expressed his thoughts about the unsatisfactory state of school affairs. Thus, in a report for June 17, 1883, Ya. Novytskyinoted that "there are 6 churches in the district, 7 schools are developing and ... it is terrible to imagine -22 taverns with thousands of supporters ... An unequal struggle, but we should not stop. Let the school awaken knowledge, and sooner or later the people will bless it" (Novytskyi, 2007, p.71).

\section{Conclusions}

Zemsky schools, thanks to the pedagogical innovations of M. Korf and Ya. Novytskyi, gradually stepped on the path of general developmental learning, and the organization of independent activities of students was established as the basis of the teaching methods. The main functions were associated with the activation of the independent work of schoolchildren through various means, methods, and techniques of instruction (excursions, practical tasks, the collection of folklore, the study of the native language and culture). Analysis of the conceptual approaches of teachers allows suggesting that their activities formed the foundation of the pedagogy of the present. Critically assessing the government policy in the field of education and activities of zemsky schools, advanced teachers, including M. Korf and Ya. Novytskyi, proposed fundamentally new approaches to solving the strategic tasks of the school and the preparation of a teacher capable of selflessly educating a child's personality. The decisive factor is that during this period, the image of the teacher is formed - it is characterized not only from the perspective of the profession and teacher's status in society, has certain qualifications, but also has a vocation to educate the mind and heart of the student.

The pedagogical heritage of public figures M. Korf and Ya. Novytskyi played a significant role in the formation and development of primary education in the Northern Azov region, as well as throughout Ukraine. They laid the foundation for the organization of the educational process in 
elementary school, which in modern times is the foundation for creating a new educational system in Ukraine, aimed at introducing innovative technologies for organizing the educational process and updating the content of national education in the new Ukrainian school.

\section{References}

Collection of resolutions of the Berdyansk district zemsky assembly from 1866 to 1908, V.2 (n.d.). Institute of Art Studies, Folklore Studies, and Ethnology (n.d.). M.T. Rilsky National Academy of Sciences of Ukraine. Institute of Manuscripts. F. 4-1/1.

Korf, N. (1877). Utilitarian and developmental education in public school. Folk school, 5, 45-48.

Korf, N. A. (1871). Our friend. St. Petersburg.

Korf, N. A. (1882). Manual for repeating schools. St. Petersburg.

Korf, N. A. (1886). Russian elementary school. A guide for zemsky councilors and teachers of rural schools. St. Petersburg.

Novytskyi, Ya. P. (2007). Works in 5 v. Yakiv Pavlovych Novytskyi. V.1. Zaporizhzhia: AA Tandem.

Piskun, G. (1914). The pedagogical activity of baron N. A. Korf. N. Novgorod.

Reports to the Aleksandrovsky school sonnet by its members F.F. Maleev, D.T. Gnedin, E.I. Shabelsky, Baron N.A. Korf and Von Schwartz on the revision of the school of 1871-1872 yr. by each of them. Ekaterinoslav. (1872).

Skilskyi, D. M. (2012). History of Ukrainian Pedagogy: An Illustrated Textbook. Ternopil: Bohdan.

State archive of Zaporizhzhya region. F.56. Op.1. Comp.36. The report of the school curator on June 17. (1883).

Vernadsky National Library of National Academy of Sciences of Ukraine. Institute of Manuscripts. F. Kh. No. 5145. The life record of Yakov Pavlovich Novytskyi. Ark. 10. (n.d.).

Vovk, L. P. (1994). The history of adult education in Ukraine. Kyiv: UDPU. 